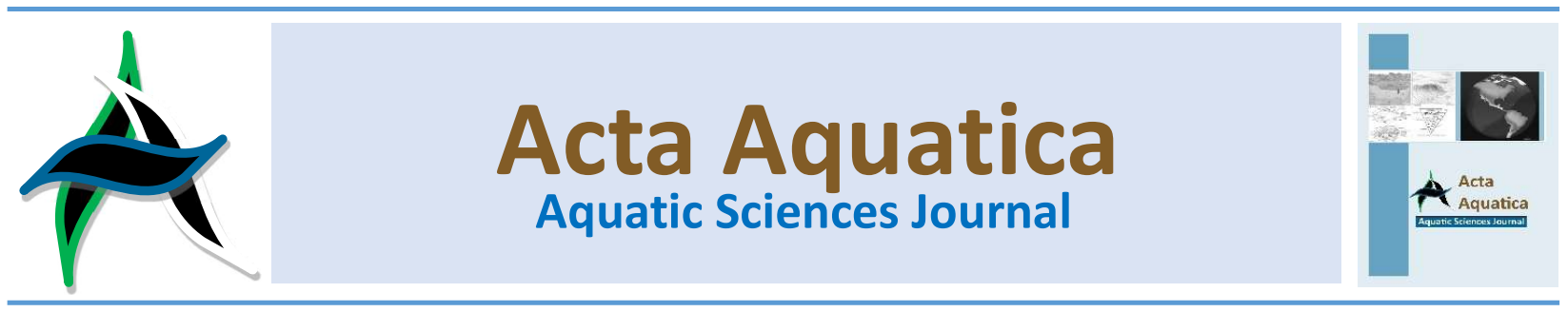

Pengaruh Pemberian Kombinasi Cacing Sutra (Tubifex sp.) Dengan Pakan Komersil terhadap Pertumbuhan Benih Ikan Lele (Clarias sp.)

\title{
The Influence of Feeding Combination Silkworm (Tubifex sp.) with Commercial Feed on Growth Performance of Catfish (Clarias sp.)
}

\author{
Dewi Agustina ${ }^{a}$ dan Retno Cahya Mukti ${ }^{a^{*}}$ \\ a Program Studi Budidaya Perairan, Fakultas Pertanian, Universitas Sriwijaya
}

\begin{abstract}
Abstrak
Penelitian ini bertujuan untuk mengetahui pertumbuhan benih lele (Clarias sp.) dengan pemberian kombinasi cacing sutra (Turbifex sp.) dan pakan komersil. Penelitian ini telah dilaksanakan pada bulan Agustus - Oktober 2020 di kelompok budidaya ikan Mitra Binaan PT. ASABRI llir Timur II Palembang, Suamtera Selatan. Perlakuan yang digunakan pada penelitian ini yaitu pemberian pakan $100 \%$ cacing sutra (kontrol) dan perlakuan kombinasi pakan yang terdiri dari $75 \%$ pakan komersil dan $25 \%$ cacing sutra. Parameter yang meliputi pertumbuhan bobot mutlak, pertumbuhan panjang mutlak, efisiensi pakan, kelangsunngan hidup, serta kualitas air. Hasil yang diperoleh dari peenlitian ini menunjukkan bahwa pemberian pakan kombinasi (P1) mendapatkan hasil yang lebih baik dibandingkan pelakuan kontrol (PO) dengan data pertumbuhan bobot mutlak sebesar $8,38 \mathrm{~g}$ panjang mutlak $7,39 \mathrm{~cm}$, efisiensi pakan $56,38 \%$ dan kelangsungan hidup $87,5 \%$.
\end{abstract}

Kata kunci: cacing sutra, ikan lele, kombinasi, pakan komersil,

\begin{abstract}
This study aims to determine the growth of catfish (Clarias sp.) Seeds by giving a combination of silkworms (Tubifex sp.) and commercial feed. This research was conducted in August October 2020 in the fish farming group of PT ASABRI, West Ilir II Palembang, South Sumatera. The treatments used in this study were $100 \%$ silkworm (control) feeding and a combination of feed treatment consisting of $75 \%$ commercial feed and $25 \%$ silkworms. Parameters include absolute weight growth, absolute length growth, feed efficiency, survival, and water quality. The results obtained from this study indicate that combination feeding (P1) obtained better results than the control (P0) with absolute weight growth data of $8.38 \mathrm{~g}$, absolute length $7.39 \mathrm{~cm}$, feed efficiency $56.38 \%$ and survival $87.50 \%$.
\end{abstract}

Keywords: catfish, commercial feed, combination, growth silkworm,

\section{Intoduction}

Catfish (Clarias sp.) One commodity that has been developed. Catfish often have domestic and foreign markets, often exported in the form of whole (whole around), cut meat (fillet), without gills and entrails (whole gill gutet) and without a head (head less). (Muallah et al., 2019). The high production of catfish causes the demand for seeds to also increase. The demand for catfish seeds in the market is quite high, namely \pm 500,000 heads in one week (Arief et al., 2014).

The increasing demand for seeds requires business actors to increase the supply of seeds with good quality and quality (Amanta et al., 2015). Provision of fish seeds can be done through hatchery activities. Amanta et al., (2015) stated that hatchery activity is one of the successes in cultivation business. The rate of growth and survival of the seeds can be seen from the selection of the parent, the quality of the water and the feed given according to the nutritional needs of the fish seeds.

Feed used for seed catfish include natural feed and commercial feed. Natural feed used is silk worms (Tubifex sp). The use of natural food in the form of $100 \%$ silk worms requires a large amount of capital in some catfish farmers (Madinawati et 
al, 2011). According to Setiawan et al., (2018), silk worms have quite expensive prices ranging from IDR $100,000 / \mathrm{kg}$ to IDR $125,000 / \mathrm{kg}$. Meanwhile, if using $100 \%$ artificial feed, the digestive system of fish seeds is still simple both in terms of morphology and physiology (Nurhayati et al., 2014). To overcome this problem, a combination of natural feed and artificial feed is used.

According to Amanta et al., (2015), a combination of artificial feed and natural feed in order to create a balance of amino acids in the body of fish seeds, because amino acids come from animal and vegetable protein which will meet the amino acid needs needed by catfish seeds. Research conducted by Amanta et al., (2015) showed that feeding with a combination of $75 \%$ pellet flour $25 \%$ silkworms in African catfish seeds resulted in optimal growth compared to using $100 \%$ silk worms and $100 \%$ commercial feed. In research Muallah et al., (2019), feeding a combination of $75 \%$ pellets and $25 \%$ silk worms accelerate the growth rate of fish fry catfish the size of $1 \mathrm{~cm}$. The aim of this study to determine the effect of the combination of silk worms and commercial feed on the growth and survival on the seed catfish.

\section{Materials and Methods}

\subsection{Time and Place}

This study was conducted in August-October 2020 in the fish farming group Partners PT.ASABRI, Ilir Timur, Palembang, South Sumatra.

\subsection{Materials and tools}

The tools used in this study include an aquarium with a size of $60 \times 30 \times 60 \mathrm{~cm}^{3}$, an aerator, an aeration hose, an aeration stone, a scale, a sipon hose, a thermometer and a $\mathrm{pH}$ meter. While the materials used include catfish seeds with a size of $3 \mathrm{~cm}$, fresh silk worms, potassium permanganate, and commercial feed with a protein content of $40 \%$.

\subsection{Research design}

This study used an experimental method, which was conducted to examine the effect of a combination of feed on the growth and viability of catfish seeds. The treatment given is: Treatment A: control ( $100 \%$ silk worm)

Treatment B: combined feed ( $25 \%$ silkworm and $75 \%$ commercial feed)

\subsection{Research procedures}

\subsubsection{Preparation of research containers}

The container used is an aquarium. Before use, the container is cleaned first, after that the aquarium is soaked with potassium permanganate (PK) for 1 night. Then the aquarium is rinsed with water and dried and then filled with $20 \mathrm{~L}$ of water, the water used in the aquarium is first deposited for 24 hours, and an aerator is installed which is used as oxygen supply to the aquarium.

\subsubsection{Fish maintenance}

Stocking done in the morning, with a density of 2 fish / $\mathrm{L}$ (Amanta et al., 2015). Before stocking, the fish are acclimatized for 15 minutes, after that the fish are adapted for 7 days, then the fish are weighed and measured for their length. Fish rearing is carried out for 40 days by feeding 3 times a day, namely at $09.00,13.00$, and 17.00WIB with time intervals every 4 hours. The amount of feed is as much as $10 \%$ of the total weight of fish seeds (Amanta et al., 2015). The silk worms used were obtained from Pasar 16 ilir Palembang. Before being given, silk worms are cleaned first, silk worms are given fresh and whole without being chopped. Checking the water quality and health of the fish during the rearing period is carried out once a week. Fish sampling is carried out every 7 days and if there are dead fish, they will be weighed and measured their length. Fish maintenance is carried out for 42 days.

\subsubsection{Water Quality Management}

The water quality was measured was the temperature and $\mathrm{pH}$. Water quality measurements are carried out in the morning at $06.00-07.00$ WIB before feeding (Muallah et al., 2019). Metabolic waste disposal is done every morning before feeding. The addition of water is done manually as much as the wasted water from the water that has been deposited in the reservoir.

\subsection{Parameters}

\subsubsection{Growth}

The absolute weight growth

The absolute weight growth of catfish during maintenance can be calculated using the following formula:

$$
\mathrm{G}=\mathrm{Wt}-\mathrm{Wo}_{\mathrm{O}}
$$

Information:

G : Absolute weight growht (g)

Wt : Average weight of fish at the end of rearing (g)

Wo : Average weight at fish the beginning of rearing (g)

The absolute lenght growth

The absolute length growth of catfish during rearing can be calculated using the following formula:

$$
\mathrm{Pm}=\mathrm{Lt}-\mathrm{Lo}
$$

Information:

$\mathrm{Pm} \quad$ : Absolute length growth $(\mathrm{cm})$

Lt : Average length of fish at the end of maintenance $(\mathrm{cm})$

Lo : Average length of fish at the beginning of rearing $(\mathrm{cm})$

\subsubsection{Feed Efficiency}

Feed Efficiency is calculated using the following formula:

$$
\mathrm{EP}=\frac{(\mathrm{Wt}-\mathrm{Wd})-\mathrm{Wo}}{\mathrm{F}} \times 100
$$

Information:

EP : Feed efficiency (\%)

Wt : Fish biomass at the end of maintenance $(\mathrm{g})$

Wo : Fish biomass at the start of rearing $(\mathrm{g})$

Wd : Biomass of dead fish (g)

$\mathrm{F} \quad$ : Amount of feed given (g)

\subsubsection{The survival rate}

The survival rate $(S R)$ of fish is calculated by the formula:

$$
\mathrm{SR}=\mathrm{Nt} / \mathrm{No} \times 100
$$

Information:

SR : Survival (\%)

$\mathrm{Nt} \quad$ : Number of fish at the end of maintenance (fish)

No : Number of fish at the beginning of maintenance (fish) 


\section{Results and Discussion}

\subsection{Growth}

Weight growth in PI treatment showed higher results than that in P0 (Figure 1). The growth in absolute weight of fish $\mathrm{P} 0$ was $7.81 \mathrm{~g}$, while in $\mathrm{P} 1$ treatment was $8.38 \mathrm{~g}$.

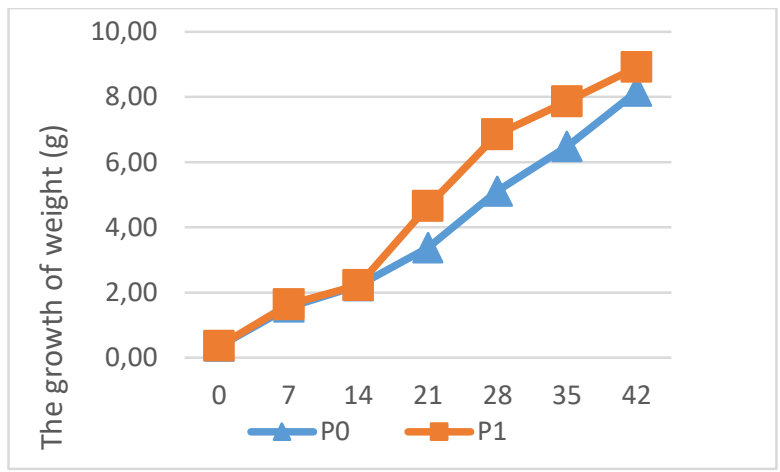

Figure 1. Graph weight growth catfish

The absolute length growth of fish P0 is $7.04 \mathrm{~cm}$ and in P1 treatment is $7.39 \mathrm{~cm}$. The length growth of catfish during maintenance is presented in Figure 2.

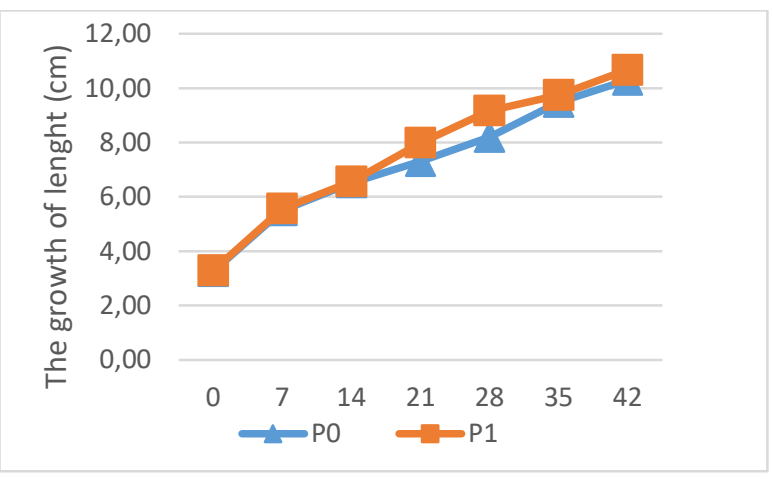

Figure 2. Graph lenght growth catfish

The nutritional content in the feed affects its growth and development, high protein feed will accelerate the development of its body (Hamron et al., 2018). Fish need high protein for growth and through high protein fish can quickly grow and develop (Rihi, 2019). According to Tjodi et al, (2016), that in fish feed protein that comes from a combination of various sources produces better nutrient value than any single source. According to Hariati (2010), silk worms contain $51.9 \%$ protein, $20.3 \%$ carbohydrates, $22.3 \%$ fat, and $5.3 \%$ ash. The use of a combination of commercial feed and silkworms together can result in higher growth.

\subsection{Feed eficiency}

The data of catfish feed efficiency during maintenance in Figure 3 shows that the feed efficiency at P0 was $66.23 \%$ higher than the P1 treatment which was $56.38 \%$.

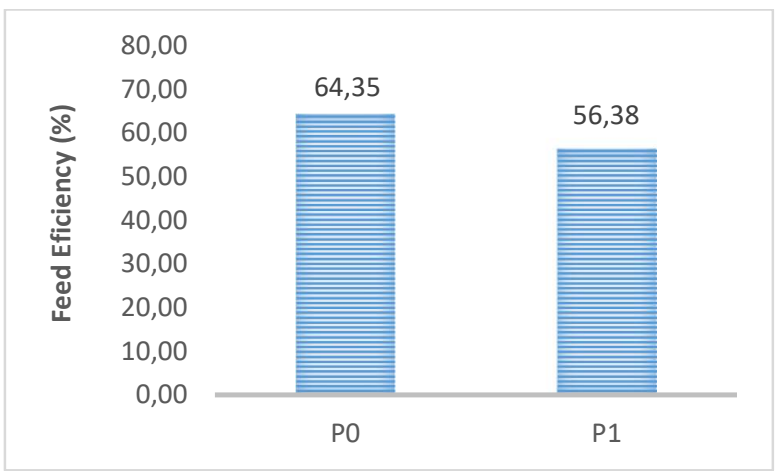

Figure 3. Graph of catfish feed efficiency

The data of catfish feed efficiency during maintenance in Figure 2 shows that the feed efficiency at P0 was $66.23 \%$ higher than the $\mathrm{P} 1$ treatment which was $56.38 \%$, this is presumably due to the difference in feed given.

According to Prasetya et al., (2020) differences in the type of feed given can affect digestibility and fish growth better, this difference is due to the presence of substances and nutrients contained in the combination feed of silk and commercial worms. Bokings et al., (2017) stated that artificial feeding and silk worms and their combination have a positive effect on the growth and survival of catfish seeds. In addition, the high feed efficiency control is due to feeding only using natural silk worm feed which is easily digested by catfish seeds during maintenance so that the total efficiency is high (Muallah et al., 2019).

\subsection{Survival rate}

The survival rate in $\mathrm{P} 0$ fish was $85 \%$ and $\mathrm{P} 1$ treatment was $87.5 \%$. The survival of catfish is presented in figure 4 .

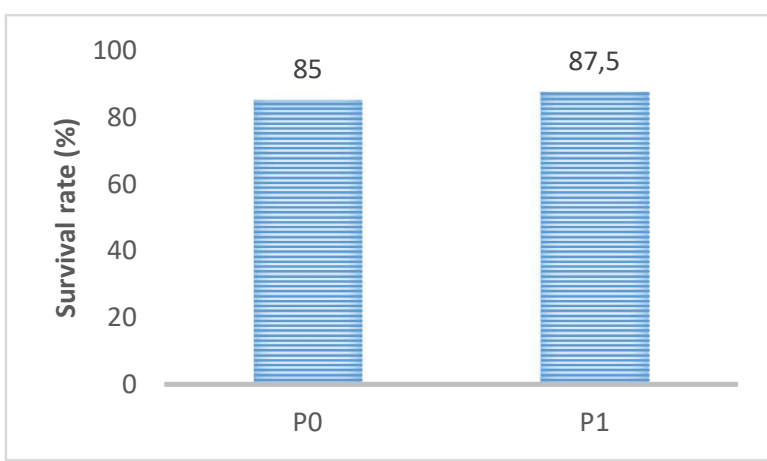

Figure 4. Graph survival of catfish

From these results it can be seen that the survival rate of catfish in the combination of feed treatment is higher than that of control fish. Survival is influenced by the quality of the water and feed that is given (Rosmawati and Muarif, 2010). In addition, it is suspected that feeding silk worms provides stimulation for fish to eat, the amount of feed is always available, and contains the protein needed by fish and does not reduce water quality in the maintenance medium (Madinawati et al., 2011).

\subsection{Water quality parameters}

From the temperature measurement on the control during maintenance the range was $28.4 \mathrm{C}-30.1 \mathrm{C}$ and in the combination feed treatment the range was $28.6 \mathrm{C}-30.2 \mathrm{C}$. During maintenance, the temperature fluctuates due to the influence of environmental temperature, it is suspected that the placement of the maintenance media container is outside the open space (outdoor) so that it often causes fluctuations in the water 
temperature of the maintenance media caused by heat and rain (Simanullang and Usman, 2018). According to Afifi (2014), catfish has a tolerance for temperatures of $22-34^{\circ} \mathrm{C}$. The $\mathrm{pH}$ value in the treatment ranged from 6.7 to 7.7 and in the treatment ranged from 6.4 to 7.9. According to Afifi (2014), states that catfish have a tolerance to the degree of acidity $(\mathrm{pH})$ in the range of 6-9. The level of $\mathrm{pH}$ acidity is much influenced by several factors of formation, including organic matter, low soil $\mathrm{pH}$ and water $\mathrm{pH}$ followed by the accumulated organic matter content and no complete oxidation occurs (Hamron et al., 2018).

\section{Conclusion}

The use of a combination feed of silk worms (Tubifex sp.) With commercial feed on catfish seeds or P1 treatment obtained better results than the control or treatment P0, namely the absolute weight growth data of $8.38 \mathrm{~g}$, absolute length $7.39 \mathrm{~cm}$, feed efficiency $56.38 \%$, and survival $87.5 \%$.

\section{References}

Afifi, I.M. 2014. Pemanfaatan Bioflok pada Budidaya Ikan Lele Dumbo dengan Padat Tebar Berbeda terhadap Laju Pertumbuhan dan Survival Rate (SR). Skripsi. Surabaya.

Amanta, R., Usman, S., Lubis, M.R.K., 2015. Pengaruh kombinasi pakan alami dengan pakan buatan terhadap pertumbuhan benih ikan lele dumbo (Clarias gariepinus). Jurnal Aquacoast marine. 3(3): 1-12.

Arief., M., Fitriani, N., Subekti, S., 2014. Pengaruh pemberian probiotik berbeda pada pakan komersil terhadap pertumbuhan dan efisiensi pakan ikan lele sangkuriang (Clarias sp.). Jurnal IImiah Perikanan dan Kelautan. 6 (1): 49-53.

Bokings, U.L., Koniyo, Y., Juliana. 2017. Pertumbuhan dan kelangsungan hidup benih ikan patin siam (Pangasius hypophthalmus) yang diberi pakan buatan cacing sutra (Tubifex sp.) dan kombinasi keduanya. Jurnal IImiah Perikanan dan Kelautan. 5 (3): 82 -89.

Hamron, N., Johan, Y., Brata, B., 2018. Analisis pertumbuhan populasi cacing sutra (Turbifex sp.) sebagai sumber pakan alami ikan. Jurnal Penelitian Pengelolaan Sumberdaya Alam dan Lingkungan.7(2): 79-89.

Hariati. E.,2010. Potensi tepung cacing sutera (tubifex sp) dan tepung potensi tepung topika untuk subtitusi pakan (pangasius hypophtalmus). Skripsi Universitas Atma jaya Yogjakarta.

Madinawati., Serdiati, N., Yoel., 2011. Pemberian pakan yang berbeda terhadap pertumbuhan dan kelangsungan hidup benih ikan lele dumbo (Clarias gariepinus). Media Litbang Sulteng 4 (2): 83-87.

Muallah, A., Diniarti, N., Astriana, B.I., 2019. Pengaruh penambahan cacing sutra (Tubifex sp.) sebagai kombinasi pakan buatan terhadap efisiensi pemanfaatan pakan dan pertumbuhan larva ikan lele sangkuriang (Clarias gariepinus). Jurnal Perikanan. 9 (2): 160-171.

Nurhayati, Utomo, N.B.P., Setiawati, M., 2014. Perkembangan enzim pencernaandan pertumbuhan larva ikan lele dumbo, Clarias gariepinus Burchell 1822, yang diberi kombinasi cacing sutra dan pakan buatan. Jurnal Ikhtiologi Indonesia.14 (3) :167-178.

Prasetya, O.E.S., Muarif., Mumpuni, F.S., 2020. Pengaruh pemberian pakan cacing sutera (tubifex sp.) dan daphnia sp. terhadap pertumbuhan dan tingkat kelangsungan hidup larva ikan lele sangkuriang (Clarias gariepinus). Jurnal Mina Sains. Vol 6 (1). ISSN: 24079030.
Rihi, A.P., 2019. Pengaruh pemberian pakan alami dan buatan terhadap pertumbuhan dan kelangsungan hidup benih ikan lele dumbo (Clarias gariepinus burchell.) di Balai Benih Sentral Noekele Kabupaten Kupang. BIOEDU, 4(2): 56-62.

Rosmawati dan Muarif. 2010. Kelangsungan hidup dan pertumbuhan benih ikan lele dumbo (Clarias sp.) pada system resirkulasi dengan kepadatan berbeda. Sains Akuatik 13 (2): $1-8$.

Setiawan., A., Yulisman., Sasanti, A.D., 2018. Periode waktu pengantian cacing sutera dengan ikan rucah sebagai pakan benih ikan gabus (Channa striata). Jurnal Akuakultur Rawa Indonesia. 6(1): 37-50.

Simanullang, A.D dan Usman, S., 2019. Pengaruh Frekuensi Pemberian Pakan Alami Cacing Sutra (Tubifex sp.) terhadap Pertumbuhan dan Kelangsungan Hidup Larva Ikan Lele (Clarias sp.). Skripsi. Universitas Sumatera Utara.

Triyanto H, Rosmawati, Widiyati A. 2016. Kebutuhan Jumlah Pakan Pada Pemeliharaan Ikan Tengadak (Barbonymus schwanenfeldii) di Kolam. Jurnal Mina Sains. Vol: 2(1): 45-52. 